\title{
<総説 >
}

\section{胎児、新生児そして小児における成長と脂質代謝に関する研究}

\author{
岡田知雄 \\ 日本大学医学部小児科学系小児科学分野 \\ 干173-8610 東京都板橋区大谷口上町 30-1 \\ 電話:03-3972-8111、Fax:03-3957-6186、 \\ E-mail:tomokada@med.nihon-u.ac.jp \\ キーワード : 新生児リポタンパク代謝、体脂肪蓄積、de novo lipogenesis、epigenetic、 \\ stearoyl-CoA desaturase(SCD)
}

\section{Developmental Roles of Lipid Metabolism in Fetus, Infant and Children}

\author{
Tomoo Okada M.D. \\ Department of Pediatrics and Child Health, Nihon University School of Medicine \\ 30-1 Oyaguchi Kamicho, Itabashi-ku, Tokyo 173-8610, Japan
}

\section{Summary}

De novo lipogenesis appeared to be an important concept of development from fetus and neonate through childhood obesity. Our study of lipoprotein analysis regarding to 'de novo lipogenesis' in fetus and neonate, which indicated the association with pulmonary surfactant synthesis, central nervous system constituents and subcutaneous fat accumulation. These events were happened to begin for the preparation of adaptation mechanism to extra-uterine life from late gestation. Especially it was found that VLDL-TG levels in cord blood revealed drastically increasing over than 32 gestational week, which may be contained the fatty acid derived from de novo lipogenesis and maternal circulation via placenta. However low birth weight infants often observed that excessive subcutaneous fat accumulation was produced by acceleration of stearoyl-CoA desaturase(SCD) activity because of catch up in infancy but which sometimes leading to obesity in later life, and then also observed the relationship between abdominal obesity and the acceleration of SCD activity in adolescence. In our study series, it was suggested that 
lipogenesis may play an important role for health and disease during fetus to adolescence, so we need to further study nutritional aspects of fatty acid for prevention of life-style related diseases early in life. And from the point of view to resolve the mechanism of epigenetic mechanism in low birth weight, it was considered that fatty acid nutritional treatment in infancy might be one of the important contributions for controlling impaired lipogenesis, especially for repressing the activity of SCD.

Key words: neonatal lipoprotein metabolism, adiposity, de novo lipogenesis epigenetic stearoyl-CoA desaturase(SCD)

\section{1. はじめに}

ヒトが胎児から成長して行く過程において脂質・脂肪酸の重要性は、よく指摘される ところではあるが、これを総合的に諸臓器の成長という観点からとらえた研究は少ない。 しかし、近年、7-dehydrocholesterol- $\Delta$ 7-reductase (DHCR7)が久損する低コレステロール 血症のために、全前脳胞症などの中枢神経奇形を呈する Smith-Lemli-Opitz syndrome (SLOS)における研究から、SHH のシグナリングに貢献するコレステロールの役割の認 識 1)や.Anderson 病におけるカイロミクロン転送蛋白が欠損する SAR1B 遺伝子の同定 2)は、新たな成長期におけるリポ蛋白代謝の見直し、すなわち成長期特有のリポ蛋白代 謝は、動脈硬化を前提としたものとは異なった、知見をもたらすと考えられる。また、 一方、近年胎児プログラミング 3) と成人期における生活習慣病との関連についての研究 が注目を集めるようになり、Developmental origins of health and disease (DOHaD)の 概念 $\left.{ }^{4}\right)$ に関する動物実験や疫学研究が集積されるにおよび、DOHaD の重要なメカニズ ムの一つである epigenetic に対し、 lipogenesis とリポタンパク代謝の接点として脂質・ 脂肪酸栄養と成長との関係についてのアプローチを必要とすると考えられる。

\section{2. 妊娠末期から新生児にかけての HDL サブクラス}

ヒト胎児のリポ蛋白プロファイルは、成人と異なる。臍帯血の LDL コレステロール 濃度は、成人のそれの約 3 分の 1 であり、TG に富みコレステロールに乏しい内容であ る 5)。対照的に HDL コレステロール濃度は、成人のそれの約半分と高く、しかもアポ $\mathrm{E}$ 濃度の高いアポ $\mathrm{E}$ リッチ HDL の占める割合が高く6)、エステル化がそしくなってい るのである ${ }^{7}$ 。 多くの成人哺乳類と同じように、ヒト胎児では HDL が主要なコレステ ロールのキャリアーなのである 8)。SLOS にては自己でのコレステロール産生が殆どで きず、胎盤からの HDL コレステロールの efflux が正常児よりも充進しており出生前の 母体から供給されるコレステロールにより、重症度が和らげられるという9)。

ヒト胎児の HDL のプロファイルは、コレステロールの供給の起源が、内因性であろ 
うが胎盤を経由する外因性であろうが、コレステロールの逆転送よりも、むしろ多くの 量のコレステロール転送を必要とする急激に成長する胎児の組織や臓器にとっては好 都合である。HDL は、均一な粒子ではなく、いくつかのサブクラスで構成され、それ らは、成人の動脈硬化の研究では異なった役割を演じることが報告されている 10）。成人 と比べて、臍帯血では全 HDL 濃度が低いにも関わらず、新生児期には small HDL 濃度 は、他と比べて絶対的に高く、しかもまた、ほぼ同程度に相対的に多くの large HDL が 占めている 11)。新生児における small HDL の増加は、LCAT 活性の低いためによると 推測され 7)、small HDL は、HDL を大型化するために遊離コレステロール（非エステ ル型コレステロール）を供給し、結果的にコレステロールの逆転送を抑圧している。新 生児における large HDL 産生のメカニズムは、まだ明確ではないが、これにはアポ $\mathrm{E}$ かアポC-Iが豊富である 12 。臍帯血におけるアポEリッチHDL濃度は成人の約 2 倍で、 臍帯血全 HDL 中の 30\%以上を占めている 7)。アポE リッチ HDL からのコレステロー ル供給は、中枢神経系のノイロンの成長にとって本質的であることが知られている 13,14)。 さらに、アポ $\mathrm{E}$ 多型は、脳成長の一つの決定因子であるばかりでなく 15 、人工心肺を 回すことによる CN S 易障害性の点でヒト乳児における心臓病手術の神経成長予後に関 与している 16)。

一方、Kwiterovich ら 12) は、新生児で低出生体重児や早産児は出生時に large アポ C-I リッチの HDL が増加していることを示し、アポ C-I リッチ HDL が培養ヒト動脈 壁平滑筋のアポトーシスを促進する故に、もしこのようなリポ蛋白が小児から成人期ま で持ち越されるならば、心血管病のリスクファクターの一つとなり得ると推測している。 以上のような所見は、 large HDL 粒子は、後の人生における心血管病のリスクだけでな く、成長や新生児期の神経学的発達としても重要あることを示唆している。

\section{3. 低出生体重児と LDL}

低出生体重児と低 HDL-コレステロール、高 TG 值との関連性 17-19)や、出生時の低身 長と総コレステロール高值、LDL-コレステロール高值およびアポ $\mathrm{B}$ 高值との関連性を 指摘している報告もみられる 20,21 。出生時のサイズと冠動脈疾患との関係についてのメ カニズムについて、自然なまたは動物モデルでの実験や検討がなされてきたが、これら の研究の結果、糖質コルチコイドが子宮内プログラミングとして一つのキーロールを有 すると推測されている 22$)$ 。子宮内の低栄養の動物モデルの研究で、後の成人期に高コレ ステロール血症へ進展する事が報告されている 23,24 。最近のヒトにおける研究において も、低出生時体重児は、成人において高コレステロール血症となる事も知られている 25)。 しかしながらながら、高コレステロール血症と出生児の体格との関係についてはヒト成 績では意見の分かれるところである。ある思春期の双子研究では、子宮内環境因子では なくて遺伝的因子が、低出生時体重と高 TC、高 LDL-C、高アポ B との関係を説明して 
いた 26)。また、メタアナリシス研究では 27)、思春期における出生体重と血中コレステ ロール濃度は弱い相関にすぎず、出生体重の意義として重視されない。

ヒト胎児においては、肝の LDL レセプター活性の増加は、在胎週数と正の相関を示 し、血中の LDL コレステロール濃度とは負の相関にある 28)。さらに、胎児において、 コレステロールを利用する主要な臓器は副腎であり、副腎の発達は、LDL コレステロー ル濃度に大きく影響するのである ${ }^{29)}$ 。それゆえに、臍帯血の LDL プロファイルは、早 産児や低出生体重児ではむしろ高い值を示し 30), 胎児の栄養状態よりもむしろその成熟 段階を、特に臓器としては肝や副腎のそれ、を表しているのである。

新生児期においては、LDL プロファイルを決定しているのは，ミルクソースの違いで ある ${ }^{31}$ 。母乳による方が，人工乳によるよりも LDL や TC 濃度は高いのである $25.32 ）$ 乳児期のコレステロールの暴露が人生の後年になっての内因性コレステロール産生を 抑止している可能性がある ${ }^{33)}$ 。在胎週数の LDL プロファイルへの影響は、成人期まで 続くのか，あるいは加齢とともに変化するのか、母乳の成人期コレステロールの研究の ような長期の研究が必要とされる。

\section{VLDL と胎児プログラミング}

VLDL は、HDL やLDL とは異なった周産期のプロファイルを示す。 small for date (SFD)は、appropriate for date (AFD) と比べて、血中の TG リッチ VLDL や IDL が高 值である事が知られている ${ }^{34)}$ 。SFD における TG リッチ VLDL サブクラスの増加は、 成人動脈硬化研究の見地から、将来の冠動脈疾患とリンク寸る可能性を推測させるので ある。上述したように臍帯血における large HDL サブクラスにおけるアポ C-I リッチの 意義によるものである。アポ-C-I は $6.6 \mathrm{kDa}$ のアポリポ蛋白で、成人においてそれは VLDL、IDL および HDL の構成成分となっている。アポ C-I は、VLDL や IDL からの アポ $\mathrm{E}$ と置換し、このためリポ蛋白が血漿からクリアランスされるのが阻止され、高 TG 血症や動脈硬化を促進する。この機序に関連して、Bjorkegren ら 35,36) は、正脂血 でも冠動脈疾患 (CAD) の患者や早期の無症候性動脈硬化症患者において食後のカイロ ミクロンレムナントやVLDL レムナント中にはアポ C-Iが多く含まれている事を報告し ている。アポ C-I はまた、CETP を阻害して、HDL から VLDL へのコレステロールエ ステル（CE）の転送をも低下させる ${ }^{37}$ 。アアポ C-I は、LCAT を刺激し HDL のコレス テロールをエステル化して、原始 HDL から球状 HDL への成熟を促進する 38)。アポ C-I の CETP と LCAT の双方に関する効果は、それゆえに、 large HDL 量の増加を促進し、 これは抗動脈硬化性であるが、もしも large HDL 上のアポ C-I がその機能を変えないな らばの話である。すなわち、たとえば、アポ C-I エンリッチド large HDL と純粋なアポ C-I の両者は、培養したヒト動脈壁平滑筋のアポトーシスを、neutral sphingomyelinase の誘導やそれに続くアポトーシスのステップヘと導く 39$)$ 。かようなアポ C-I の作用が in 
vivo でおこるなら、心筋梗塞を引き起こす不安定プラーク破裂のメカニズムに関与する ことにもなる。

\section{5. 内臓脂肪蓄積と stearoyl CoA desaturase (SCD) 一 de novo lipogenesis と胎児・新生 児成長そして肥満、 2 型糖尿病、心血管病へー}

SCD は、糖からの脂質新生系における律速段階酵素である。Phinney SD は Palmitoleic acid は比較的半減期が短いので、組織における palmitoleic acid の蓄積は そのほとんどが de nove lipogenesis を介した産生克進の結果である。したがって、 palmitoleic acid は体重増加の biomarker として用いることができるだろうと述べて いる 40)。Kunesova M は、肥満女性の一卵性双生児研究によって、肝臓で生成される、 血清中、脂肪組織中の palmitoleic acid が、環境よりも、遺伝的に強く調節されている ことを報告した ${ }^{41)}$ 。

出生後の乳児期早期に、皮下脂肪が急速に蓄積する。このとき、脂肪細胞数は増加せ ず、脂肪細胞のサイズは数倍に肥大する（妊娠末期には正常成人の $120 \%$ のサイズにな る)。出生時の皮下脂肪組織の脂肪酸組成は、小览期の脂肪酸組成と比較すると、胎児 期には palmitic acid, palmitoleic acid の割合が高く42)、この事実は、胎児期に脂肪組 織に蓄積される脂肪酸は、 de novo lipogenesis によって産生されたものではないかとい うことを推測させる。これは大変貴重な報告で、胎児は妊娠末期に、外界に適応すべく 準備を急速に始めている。あたかも脱皮するかのような、母胎から自立して行く新たな 旅立ちを思わせる。

そこで、成熟新生児の皮下脂肪蓄積におよぼす低出生体重児 (light for date : LFD) の catch up メカニズムに関する検討を行った 43)。LFD 児は、すでに生後 1 ケ月で、体 重がキャッチアップする前に皮下脂肪厚はキャッチアップしていた。また体重の catch up を認めた症例は、appropriate for date: AFD 児よりもさらに皮下脂肪をつけていた。

(すなわち、必要以上に過脂肪蓄積となる LFD は、皮下脂肪蓄積の制御調節ができな い可能性を示すものなかもしれないと推測される。可，catch up のメカニズムは、今 までに種々の仮説があげられている。高脂肪食のためであるとか、IGF1, IGF2 receptor 機能、GLUT1 の作用、そしてインスリン抵抗性などがあげられている。興味深いこと に、LFD も AFD もともに受精後 400 日に体脂肪蓄積のピークを迎えた。それだけ LFD の方が体脂肪蓄積の velocity が急峻になっていた。おそらく、 de novo lipogenesis すな わちSCD活性の克進という機構にスイッチが入ることは、生存するための外界適応の一 つの条件ではあるのだろうが、中には過剩に反応し持続してしまう例において、Barker 仮説の候補が含まれるのではなからうか。そして実際に小児肥満において、内臓脂肪指 標としてのウエスト身長比などが、SCD 活性指標である palmitoleic acid/palmitic acid 比や palmitoleic acid と有意に正相関することが示されたのであった 44)。 
子宮内胎児環境から外界 への適応として、きわめて 特徵的な成長変化に肺呼吸 があげられる。このために は胎児は肺サーファクタン トの合成が出生前急ピッチ で行われなければならない。

Figure 1 は、在胎週数と臍 帯血中VLDL-TGとの関連 を示したものであるが、 VLDL-TG は直線的に増加 するのではなく, 在胎 32 週を過ぎるとドラスティ ックに増加して行くのが わかる。そして、肺サー ファクタントの合成が悪 い呼吸窮迫症候群 RDS においては、VLDL-TG

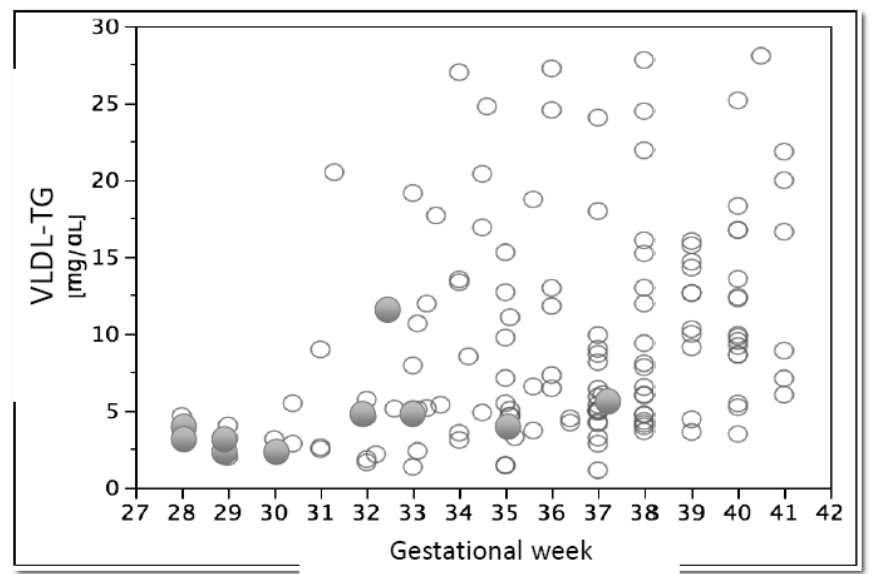

Respiratory distress syndrome

Fig.1. Relationship between VLDLD-TG levels and gestational week in cord blood. VLDLD-TG levels in cord blood appeared to remarkably increase over than 32 gestational week. Cases of respiratory distress syndrome (RDS) revealed lower levels VLDL-TG compared to none RDS.

の血中濃度が低い 45)。ハイサーファクタント合成に VLDL が関与することを実証した ラットの研究がある 46)。Normal human から抽出した VLDL を ${ }^{14}$ C-tripalmitin でラ ベルしたものを母親に経静脈的に投与する。母親の組織では、主に肺に集積するが、胎 児では肝、腎、心、肺などに広く分布する。そして、胎児肺でのサーファクタント脂質 量（リン脂質）が増加する。また、胎児肺胞細胞 typeII 中の脂肪酸組成を調べると、 palmitic acid（サーファクタントの backbone になる）、 oleic acid が増加している。こ のメカニズムとして、CCT（サーファクタント合成の律速段階酵素）の活性立進が関与 する。apoE knockout mice で VLDL 濃度が上昇すると、CCT 活性は 2 〜 倍に上昇 する。また、母体にステロイドを投与すると、CCT の活性が上昇する。以上より、胎児 肺の成熟にはVLDL からの TG の供給が重要な要素の一つであることが推測された。

\section{6. 今後の展開}

まず、早産児や LFD 巟に対する適切な栄養法の確立が望まれる。現在は、多くの場 合既製の粉乳か母乳が用いられている。中枢神経の成長においても脂質，脂肪酸栄養が 極めて重要であることは云うまでもない。近年、幼児期における学習障害や自閉症の問 題に、34-37 週の late preterm における重要性が注目されてきた。34 週以降の 6 週間 に $35 \%$ の脳重量増加が認められる。さらに、この 6 週間で、組織学的には大脳皮質（灰 
白質）の層状構造が形成され、脳回の形成も進行する。早産児やLFD 児に対しては個々 の栄養状態に応じた栄養管理が必要と思われる。

次に、肥満の管理における SCD 活性の調節がある。近年 SCD は肥満・糖尿病の治療 目標とされ、その抑制薬の効果が動物にて確認されている。われわれは、肥満小児にお いて SCD 活性とDHA との関連性に注目し、血液リン脂質中 DHA 含量が多いほど SCD 活性が低いという結果を得た。多価不飽和脂肪酸摂取による SCD 活性の抑制は動物で も確認されており、今後 LFD 児など SCD 活性立進状態での栄養管理へ展開が期待され る。

\section{7. 終わりに}

妊娠末期から思春期にかけて，特に成長の観点からリポタンパク代謝の意義について 述べた。そして脂肪酸代謝と de novo lipogenesis は、リポタンパク代謝と連動しており、 $\mathrm{DOHaD}$ の概念における今後の脂肪酸栄養の研究の展開に重要であることが示唆された。

\section{謝辞}

平成 21 年度のランズ賞学術賞に選考下さいましてありがとうございました。関係各 位に深謝いたします。

\section{参考文献}

1. R.I. Kelley, R.C.M. Hennikam, The Smith-Lemli-Opitz syndrome. J. Med. Genet. 37: 321-335, 2000.

2. Jones B, Jones EL, Bonney SA, Patel HN, Mensenkamp AR, Eichen-baum-Voline S, et al. Mutations in a Sar1GTPase of COPIIvesicles are associated with lipid absorption disorders, Nat. Genet.34: 29-31,2003

3. D.J.P. Barker, The developmental origins of adult disease. J. Am. Coll Nutr. 23: 558S-595S, 2004.

4. Gluckman PD, Hanson MA, Spencer HG, Bateson P. Environmental influences during development and their later consequences for health and disease: implications for the interpretation of empirical studies. Proc Biol Sci 272: 671-677, 2005.

5. Bansal N, Cruickshank JK, MaElduff P, Durrington PN. Cord bloodlipoproteins and prenatal influences. Curr Opin Lipidol 16: 400-408, 2005.

6. Blum CB, Davis PA, Forte TM. Elevated levels of apolipoprotein E in the high density lipoproteins of human cord blood plasma. J Lipid Res 26: 755-760, 1985.

7. Nagasaka H, Chiba H, Kikuta $H$, et al. Unique character and metabolism of high density lipoprotein (HDL) in fetus. Atheroscler 161: 215-223, 2002. 
8. Parker Jr CR, Carr BR, Simpson ER, MacDonald PC. Decline in the concentration of low-density lipoprotein-cholesterol in human fetal plasma near term. Metabolism 32: 919-923, 1983.

9. Katie T. Jenkins, Louise S. Merkens, Matthew R. Tubb, Leslie Myatt,W. Sean Davidson, Robert D. Steiner, Laura A. Woollett. Enhanced placental cholesterol efflux by fetal HDL in Smith-Lemli-Opitz syndrome. Mol Gen Metabol 94: 240-247, 2008.

10. Asztalos BF. High-density lipoprotein metabolism and progression of atherosclerosis: new insights from the HDL Atherosclerosis Treatment Study. Curr Opin Cardiol 19: 385-391, 2004.

11. Fujita H, Okada T, Inami I, Makimoto M, Hosono S, Minato M, Takahashi S, Harada K, Mugishima H, Yamamoto T. Heterogeneity of high-density lipoprotein in cord blood and its postnatal change. Clin Chim Acta. 389: 93-97, 2008 .

12. Kwiterovich Jr PO, Cockrill SL, Virgil DG, et al. A large high-density lipoprotein enriched in apolipoprotein C-I: a novel biochemical marker in infants of lower birth weight and younger gestational age. JAMA 293: 1891-9, 2005.

13. Fagan AM, Bu G, Sun Y, Daugherty A, Holtzman DM. Apolipoprotein E containing high density lipoprotein promotes neurite outgrowth and is a ligand for the low density lipoprotein receptor-related protein. J Biol Chem 271: 30121-30125, 1996.

14. Stewart JE, Skinner ER, Best PV. Receptor binding of an apolipoprotein E rich subfraction of high density lipoprotein to rat and human brain membranes. Int J Biochem Cell Biol 30: 407-415, 1998.

15. Wright RO, Hu H, Silverman EK, et al. Apolipoprotein E genotype predicts 24-month bayley scales infant development score. Pediatr Res 54: 819-825, 2003.

16. Gaynor JW, Gerdes M, Zackai EH, et al. Apolipoprotein E genotype and neurodevelopmental sequelae of infant cardiac surgery. J Thorac Cardiovasc Surg 126: 1736-1745, 2003.

17. Fall CHD, Osmond C, Barker DJP, et al. Fetal and infant growth and cardiovascular risk factors in women. BMJ 310: 428-432, 1995.

18. Frankel S, Elwood P, Sweetman P, Yarnell J, Davey Smith G. Birth weight, adult risk factors and incident coronary heart disease: the Caerphilly Study. Public Health 110: 139-143, 1996.

19. Donker GA, Labarthe DR, Harrist RB, et al. Low birth weight and serum lipid concentration at age 7-11 years in a biracial sample. Am J Epidemiol 145: 308-407, 1997.

20. Forrester TE,Wilks RJ, Bennett FI, et al. Fetal growth and cardiovascular risk factors in Jamaican schoolchildren. BMJ 312: 156-160, 1996.

21. Barker DJP, Martyn CN, Osmond C, Hales CN, Fall CHD. Growth in utero and serum cholesterol concentrations in adult life. BMJ 307: 1524-1527, 1993. 
22. Fowden AL, Forhead AJ. Endocrine mechanisms of intrauterine programming. Reproduction 127: 515-526, 2004.

23. Kind KL, Clifton PM, Katman AI, Tsiounis KM, Robinson JS, Owens JA. Restricted fetal growth and the response to dietary cholesterol in the guinea pig. Am J Physiol 277: R1675-R1682, 1999.

24. Szitanyi P, Hanzlova J, Poledne R. Influence of intrauterine undernutrition on the development of hypercholesterolemia in an animal model. Physiol Res 2000;49:721-4.

25. Davies AA, Smith GD, Ben-Shlomo Y, Litchfield P. Low birth weight is associated with higher adult total cholesterol concentration in men: findings from an occupational cohort of 25,843 employees. Circulation. 110: 1258-62, 2004.

26. Ijzerman RG, Stehouwer CD, Van Weissenbruch MM, De Geus EJ, Boomsma DI. Evidence for genetic factors explaining the association between birth weight and low-density lipoprotein cholesterol and possible intrauterine factors influencing the association between birth weight and high-density lipoprotein cholesterol: analysis in twins. J Clin Endocrinol Metab. 86: 5479-5484, 2001.

27. Owen CG, Whincup PH, Odoki K, Gilg JA, Cook DG. Birth weight and blood cholesterol level: A study in adolescents and systemic review. Pediatr. 111: 1081-1089, 2003.

28. Cai HJ, Xie CL, Chen Q, Chen XY, Chen YH. The relationship between hepatic low-density lipoprotein receptor activity and serum cholesterol level in the human fetus. Hepatology 13: 852-857, 1991.

29. Diaz M, Leal C, Ramon Y, Cajal J, Jimenez MD, Martinez H, et.al. Cord blood lipoprotein-cholesterol: relationship birth weight and gestational age of newborns. Metabolism. 38: 435-438, 1989.

30. Fujita H, Okada T, Inami I, Makimoto M, Hosono S, Minato M, Takahashi S, Mugishima H, Yamamoto T. Low-density lipoprotein profile changes during the neonatal period. J Perinatol. 28: 335-340, 2008.

31. Wong WW. Cholesterol feeding during early infancy and its effects on cholesterol homeostasis. 1st. ed. In: Huang YS and Sinclair AJ, ed. Lipids in infant nutrition. Champaign, Illinois: AOCS Press, pp 148-155, 1998.

32. Bayley TM, Alasmi M, Thorkelson T, Jones PJ, Corcoran J, Krug-Wispe S, et. al. Longer term effects of early dietary cholesterol level on synthesis and circulating cholesterol concentrations in human infants. Metabolism. 51: 25-33, 2002.

33. Jones PJH, Pappu AS, Hatcher L, Li ZC, Illingworth R, Connor WE. Dietary cholesterol feeding suppresses human cholesterol synthesis measured by deuterium incorporation and urinary mevalonic acid levels. Artherioscler Thromb Vasc Biol 16: 1222-1228, 1996. 
34. Kwiterovich PO Jr, Virgil DG, Garrett E, et al. Lipoprotein heterogeneity at birth: influence of gestational age and race on lipoprotein subclasses. Ethn Dis. 14: 351-359, 2004

35. Bjorkegren J, Boquist S, Samnegard A, Lundman P, Tornvall P, Ericsson C-G. Accumulation of apolipoprotein C-I-rich and cholesterol-rich VLDL remnants during exaggerated postprandial triglyceridemia in normolipidemic patients with coronary artery disease. Circulation. 101: 227-230, 2000.

36. Bjorkegren J, Silveira A, Boquist S, et al. Postprandial enrichment of remnant lipoproteins with apoC-I in healthy normolipidemic men with early asymptomatic atherosclerosis. Arterioscler Thromb Vasc Biol. 22: 1470-1474, 2002.

37. Gautier T, Masson D, de Barros JP, et al. Human apolipoprotein C-I accounts for the ability of plasma high density lipoproteins to inhibit the cholesteryl ester transfer protein activity. J Biol Chem. 275: 37504-37509, 2000.

38. Albers JJ, Lin J, Roberts GP. Effect of human plasma apolipoproteins on the activity of purified lecithin: cholesterol acyltransferase. Artery. 5:61-75, 1979.

39. Kolmakova A, Kwiterovich P, Virgil D, et al. Apolipoprotein C-I induced apoptosis in human aortic smooth muscle cells via recruiting neutral sphingomyelinase. Arterioscler Thromb Vasc Biol, 24:264-269, 2004.

40. Phinney SD. Fatty acids, inflammation, and the metabolic syndrome. Am J Clin Nutr. 82:1151-1152, 2005.

41. Kunesová M, Hainer V, Tvrzicka E, Phinney SD, Stich V, Parízková J, Zák A, Stunkard AJ. Assessment of dietary and genetic factors influencing serum and adipose fatty acid composition in obese female identical twins. Lipids. 37:27-32, 2002.

42. Soriguer Escofet FJ, Esteva de Antonio I, Tinahones FJ and Pareja A. Adipose tissue fatty acids and size and number of fat cells from birth to 9 years of age - A cross-sectional study in 96 boys. Metabolism 45: 1395-1401,1996.

43. Inami I, et al. Subcutaneous fat accumulation changes from birth to first year of life in SGA babies. p-089. 3rd Congress of Asian Society for Pediatric Research Oct. 8, Tokyo, 2007.

44. Okada T, Furuhashi N, Kuromori Y, Miyashita M, Iwata F, Harada K. Plasma palmitoleic acid content and body fatness in children. Am J Clin Nutr. 82:747-750, 2005.

45. Yonezawa R, Okada T, Kitamura T, Fujita H, Inami I, Makimotoa M, Hosono S, Minato M, Takahashi S, Mugishima H, Yamamoto T, Masaoka N. Very low density lipoprotein in the cord blood of preterm neonates. Metabolism 58: 704-707, 2009.

46. Ryan AJ, Medh JD, McCoy DM, Salome RG, Mallampalli RK. Maternal loading with very low-density lipoproteins stimulates fetal surfactant synthesis. Am J Physiol Lung Cell Mol Physiol. 283:L310-318, 2002. 